\title{
Acute Respiratory Infections (Pneumonia) Incidence Rate in Children due to Climatic Variables and Air Quality in Bogor
}

\section{Revia Muharrami, Rini Hidayati, Ana Turyanti}

Department of Geophysics and Meteorology, Faculty of Mathematics and Natural Sciences, IPB University, Dramaga Campus, Bogor, Indonesia 16680

\section{ARTICLE INFO}

Received

7 September 2020

Revised

10 March 2021

\section{Accepted for Publication}

22 April 2021

\section{Published}

9 June 2021

doi: 10.29244/j.agromet.35.1.39-48

\section{Correspondence:}

Rini Hidayati

Department of Geophysics and Meteorology, Faculty of Mathematics and Natural Sciences, IPB University,

Dramaga Campus, Bogor, Indonesia 16680.

Email: rinihidayati@apps.ipb.ac.id

This is an open-access article distributed under the CC BY License. (c) 2021 The Authors. Agromet.

\begin{abstract}
A B S T R A C T
Pneumonia is the respiratory infection disease, which is influenced by climatic variables and air quality. However, little is known how rainfall and air humidity influence on the disease situated in a high traffic density such as in Bogor, Indonesia. The research aims to analyze the influences of rainfall, air humidity, and air pollution on the incidence rate of pneumonia under 5-year old children in Bogor. We used statistical approaches namely correlation and principal component analysis and combined with chart analysis to identify the influences. Our results revealed that high rainfall (high relative humidity) improved air quality by lowering the concentration of particulate matter. But, the indoor microorganism growth would increase, therefore it affects the incidence rate of pneumonia under 5-year old children, especially in transition season from wet to dry. In dry season, high concentration of particulate matter in the air would increase the incidence rate of pneumonia. Other findings showed that climate (through humidity) and particulate matters have regulated the pneumonia incidence rate in Bogor. The rate was higher under high humidity. On other hand, in transition from dry to wet season, concentration of particulate matters was more dominant to influence the incident rate.
\end{abstract}

\section{KEYWORDS}

air pollution, humidity, particulate matter, principle component analysis, rainfall

\section{INTRODUCTION}

Pneumonia is an acute respiratory infectious (ARI) disease that infect humans from infants to adults. This disease is categorized as ARI with high severity, which infects the lungs tissues (lower respiratory tract). Based on WHO report, there were almost four million deaths worldwide caused by ARI each year, and $98 \%$ of them are caused by pneumonia (WHO, 2014). Biologically, children under 5-year old (toddlers) have a higher risk of pneumonia compared to adults. This is caused by the immature immune system and the absence of antibodies to fight the microorganisms causing pneumonia infection in toddlers (Popovsky and
Florin, 2020; Rodrigues and Groves, 2018; Widoyo, 2016). On the contrary, adults have already developed a matured immune system. Adults who had been infected with pneumonia during their toddler may have natural antibodies, which is able to minimize the risk of a second infection (Quinton et al., 2018). In addition, toddlers more have physical contacts with peers in their neighborhood resulting in an even higher risk to be infected by pneumonia (Sidiq et al., 2016). Toddlers' mobility is lower compared to adults, thus performing identification of pneumonia infection's spread in a certain area will be easier when using the toddlers' pneumonia case. 
Pneumonia infection is caused by micro-sized viruses, bacterias, and fungi. These microorganisms spread through the air, with the transmission occurs when viruses and bacterias released by pneumonia's infected person during coughs or sneezes are accidentally inhaled by a non-infected person (Mathew, 2018; Nathan et al., 2020). The transmission may escalate when the suitable environment met (Putra and Wulandari, 2019; WHO, 2014). Two environmental factors affecting the survival of pneumonia pathogens are weather conditions, (Chowdhury et al., 2018) and air quality (Particulate Matters) (Vodonos et al., 2016).

Previous studies revealed that the presence of $\mathrm{PM}_{2.5}$ and $\mathrm{PM}_{10}$ in the atmosphere could aggravate the air quality (Turyanti and Chaerunnisa, 2017), and further increased the number of people with ARI's symptoms (Turyanti, 2011) including pneumonia, which had been registered in health services. Other studies confirmed the relation between $\mathrm{PM}_{2.5}$ to the incidence rate (Mehta et al., 2013). One study also reported that $\mathrm{PM}_{10}$ concentration in the atmosphere was correlated to the incidence of upper respiratory tract infections in Hong Kong (Tam et al., 2014). The number of pneumonia cases in children under five registered in 41 metropolitan Atlanta hospitals and Georgia hospitals was also associated with an increasing concentration of pollutants from motor vehicles, including $\mathrm{PM}_{2.5}$ (Darrow et al., 2014). Based on this information, identification of the relationship between air quality and climatic variables with the incidence rate of pneumonia cases is important, especially in urban areas such as Bogor.

Based on INRIX 2019 Global Traffic Scorecard (a research institution and transportation agency), Bogor is in the $5^{\text {th }}$ position as the most congested city in Indonesia. Congestion is closely related to increasing concentrations of pollutants in the atmosphere, including $\mathrm{PM}_{2.5}$ and $\mathrm{PM}_{10}$ (Aida et al., 2019; Turyanti and Santikayasa, 2006), which can also lead to increasing ARI potential incidence (Pedde et al., 2017) including pneumonia (Chang et al., 2018). The climatic conditions in Bogor can either support or limit the potential of the disease. Bogor, which is located near the hillside of Mt. Gede Pangrango and Mt. Salak, has a fairly high annual rainfall and quite warm air temperatures (Hidayat and Farihah, 2020). These climatic conditions can support the survival of pneumonia pathogens (Sohn et al., 2019), thus potentially increase the pneumonia incidence. However, the concentration of pollutants in the atmosphere from traffic density and other activities will be decreased due to the deposition by rain (Kwak et al.,
2017), which otherwise lowers the potential for pneumonia incidence.

Based on these environmental elements, this study examines the relationship between climatic variables, $\mathrm{PM}$ concentration in the atmosphere, and the number of pneumonia incidence in Bogor. More specifically, this study aims to: (1) identify the relationship between environmental factor (climatic variables) and PM concentrations in the atmosphere, and (2) analyze the influence of climatic variables and PM concentrations on pneumonia incidence. As a case study, the analysis was performed using the data period of 2017-2019.

\section{RESEARCH METHODS}

\section{Data Sources}

This study required daily data of pneumonia incidence under 5-year old children in Bogor for the 2017-2019 period. The data was obtained from ten public health centers spread across Bogor. Other data were needed especially daily $\mathrm{PM}_{2.5}$ and $\mathrm{PM}_{10}$ concentration data, and daily meteorological data including air temperature, humidity $(\mathrm{RH})$, and rainfall for the 2017-2019 period in Bogor. The latter data were obtained from the Centre for Climate Risk and Opportunity Management in Southeast Asia and Pacific (CCROM-SEAP) IPB, which was collaborated with National Institute for Environmental Studies (NIES) Japan. Each analysis process was executed using data processing software namely Minitab 18 and Microsoft Excel.

\section{Analysis of the Climatic Variables Influence on PM Concentrations}

The relationship between PM and climatic variables was analyzed using correlation analysis with a confidence level of $95 \%$ or a $p$-test result value of $<0.05$. Correlation analysis was conducted to determine the degree of association and direction of the relationship between the $X$ (independent) variable and the $Y$ (dependent) variable. The correlation analysis was calculated based on the Pearson correlation coefficient in Equation (1).

$$
r=\frac{\sum\left(x_{i}-\bar{x}\right) \times\left(y_{i}-\bar{y}\right)}{\sqrt{\sum\left(x_{i}-\bar{x}\right)^{2} \times\left(y_{i}-\bar{y}\right)^{2}}}
$$

where $r$ pearson correlation coefficient, $x_{i}$ climatic variables (rainfall, temperature, and relative humidity), $\bar{x}$ average of climatic elements, $y_{i}$ pollutants concentration ( $\mathrm{PM}_{2.5}$ and $\left.\mathrm{PM}_{10}\right), \bar{y}$ average of pollutants concentration. 

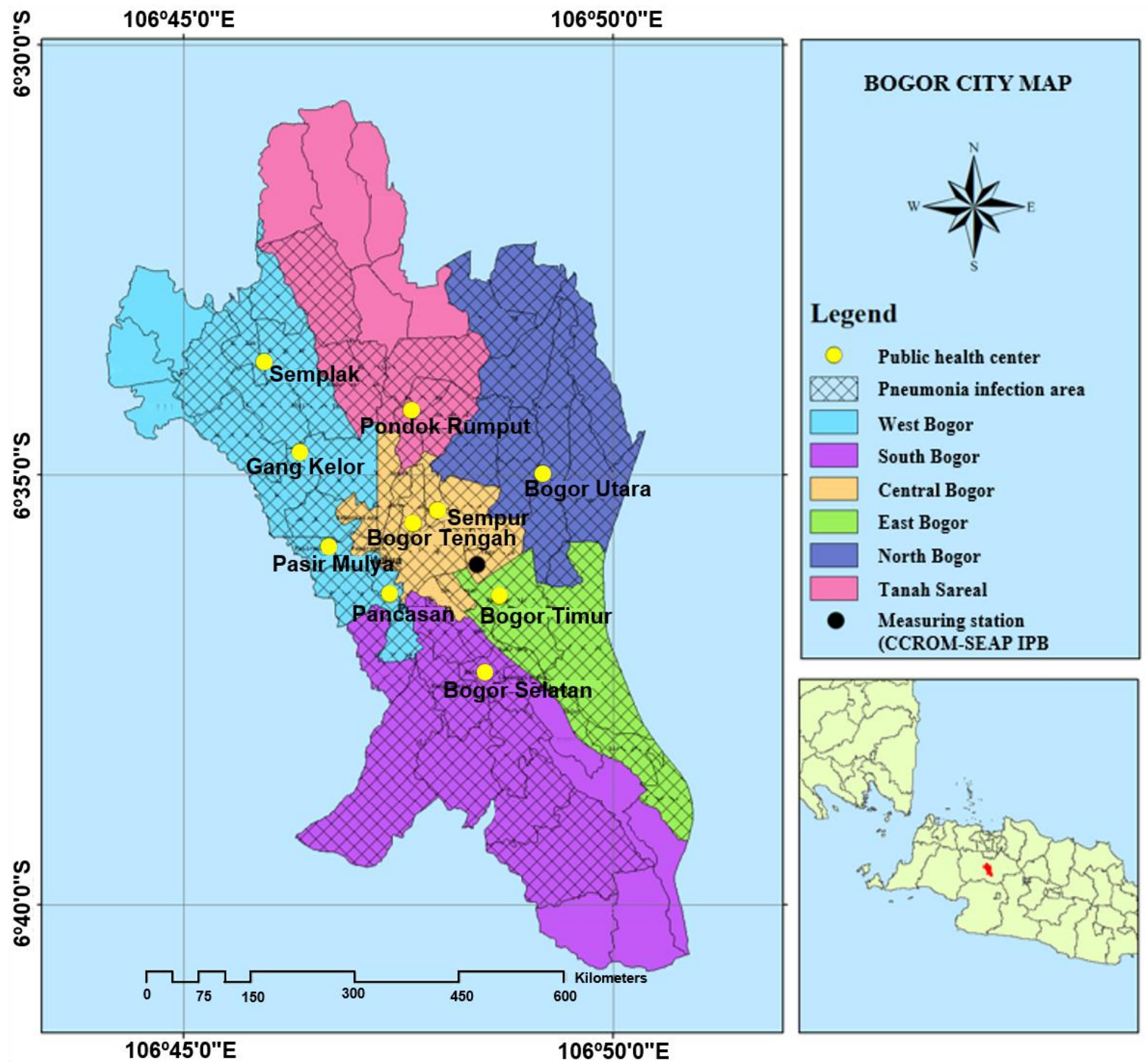

Figure 1. Study area with public health center distribution and sub-districts infected with pneumonia (based on patient address).

\section{Analysis of the Relationship between Pneumonia Incidence, Climatic Variables, and PM Concentration}

We assumed that the number of pneumonia infection cases represented the ratio of all pneumoniainfected children over time. The relationship between climatic variables and PM concentration on pneumonia incidence was analyzed using Principal Component Analysis (PCA) and visualized in a 3D-surface plot using Minitab 18 software. PCA eliminated the multicollinearity between climatic variables and PM concentration which occurred because both variables were not linearly independent. The climatic variables and the PM concentration data were first standardized to be on the same scale. PCA was then performed on the standardized data in Minitab 18 using the covariance matrix type (considering both variables were already in the same size). The proportion results described each principal component (PC), which represented the data diversity. The number of principal components used subjectively depends on the proportion that was considered sufficient to capture the data structure. The equation of the relationship between pneumonia incidence and the PCs was expressed in linear regression, where the outcoming PCs were a combination of climatic and PM data which also weighted following the values in the Eigenvector table. PCs in the regression equation result was then transformed back into the anomalies data of climatic and PM variables which resulted in linearly independent regression form of the relationship between the pneumonia incidence to standardized climatic and PM data. The anomalies data of climatic and PM variables in the equation was also transformed back into the previous climatic and PM data form by substituting the average of the climatic and PM variables in the anomaly (Equation 2).

$$
d=d_{a n}+\bar{d}
$$


where $d$ is the variable, $d_{a n}$ is the variable anomalies in the regression equation, and $\bar{d}$ is the average value of the variable.

\section{RESULTS AND DISCUSSIONS}

\section{$\mathbf{P M}_{2.5}$ and $\mathbf{P M}_{10}$ Concentration in Bogor}

Exposure to pollutants, such as Particulate Matter (PM) can aggravate respiratory infections. PM is a mixture of solid particles and droplets that come from emissions from various sources with varying sizes, mass, and chemical compositions. PM consists of various pollutants such as sulfate, nitrate, ammonia, sulfur, chloride, black carbon, and mineral dust. PMs with different sizes will also react differently in the atmosphere. The aerodynamic differences in PM will also differentiate its transmission and elimination processes in the atmosphere (McLoughlin et al., 2019; Satsangi and Agarwal, 2019).

The monthly concentrations of $\mathrm{PM}_{2.5}$ and $\mathrm{PM}_{10}$ in Bogor from 2017 to 2019 had a similar pattern. The average concentration of $\mathrm{PM}_{2.5}$ and $\mathrm{PM}_{10}$ in the wet season which represented by DJF (December-JanuaryFebruary) months were $14 \mu \mathrm{g} / \mathrm{m}^{3}$ and $38 \mu \mathrm{g} / \mathrm{m}^{3}$ with a smaller concentration range, while the average concentrations in the dry season which represented by the JJA (June-July-August) months were $35 \mu \mathrm{g} / \mathrm{m}^{3}$ and $71 \mu \mathrm{g} / \mathrm{m}^{3}$ with a wider concentration range (Figure 2).
The wide range and extreme values of PM concentration in the dry season were the results of the inconsistent daily amount of rainfall which at some point was high but occasionally there was none (Figure 2-rainfall). PM concentration during the dry season in Bogor reached up to twice as high as the average PM concentration during the wet season, which correspondence with Nishihashi et al. (2019) research.

According to the monthly average data presented in the scatter plot (Figure 3), relative humidity and PM concentration were significantly correlated with a $95 \%$ confidence level, namely -0.76 for $\mathrm{PM}_{2.5}$ and -0.71 for $\mathrm{PM}_{10}$. Rainfall and $\mathrm{PM}$ concentration was also significantly correlated, namely -0.44 for $\mathrm{PM}_{2.5}$ and -0.38 for $\mathrm{PM}_{10}$. Air temperature and $\mathrm{PM}$ concentration were significantly correlated with a positive correlation namely 0.43 for $\mathrm{PM}_{2.5}$ and 0.37 for $\mathrm{PM}_{10}$. These values indicated that the concentrations of $\mathrm{PM}_{2.5}$ and $\mathrm{PM}_{10}$ will be low if the rainfall and humidity were relatively high but tend to be high if the air temperature was also high.

PM concentration was high during the dry season due to the low amount of rainfall and humidity and vice versa. A high amount of rainfall and high humidity will escalate the wet deposition process which is the most effective mechanism for cleaning the atmosphere (Ruchiraset and Tantrakarnapa, 2020).

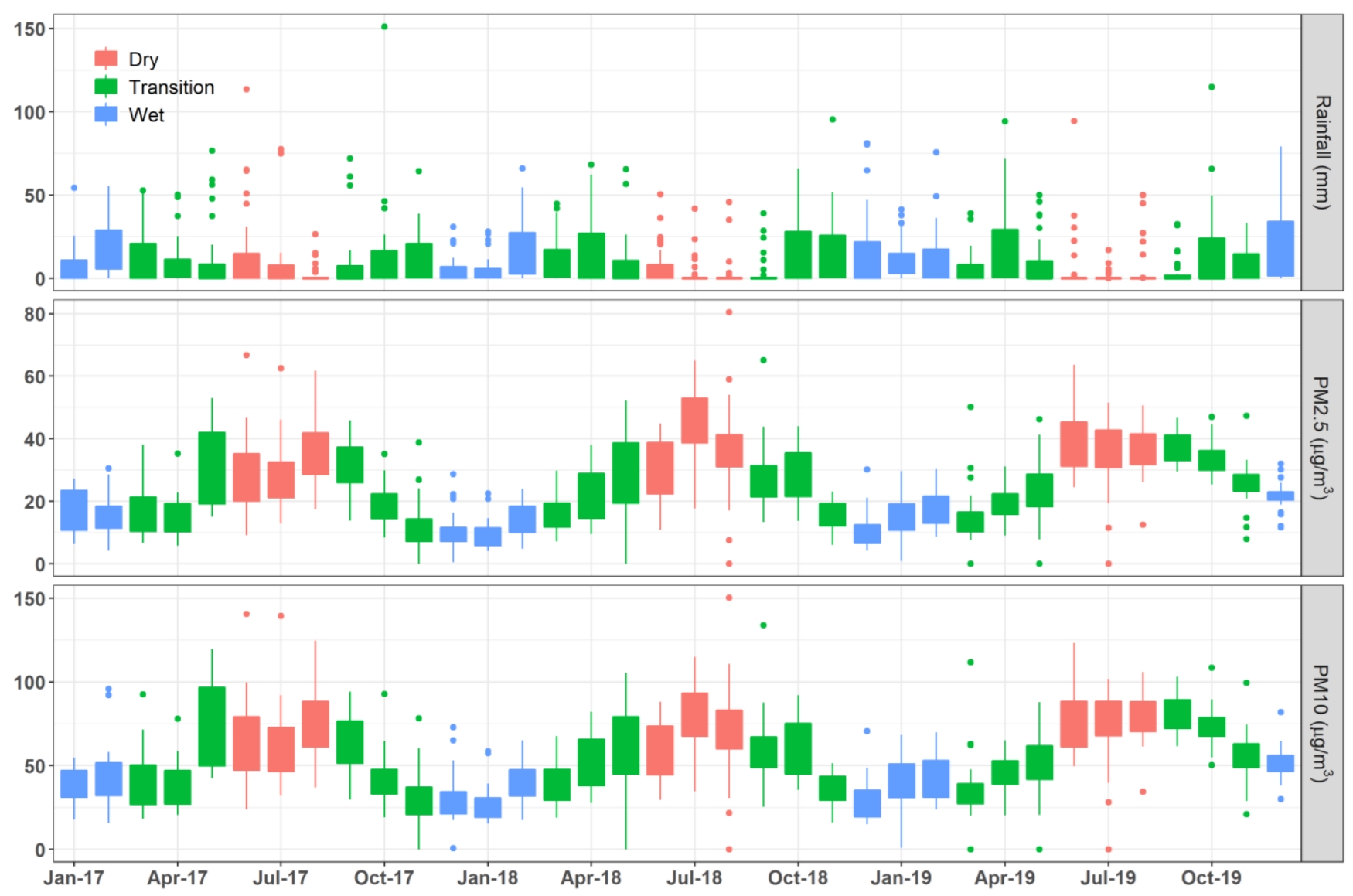

Figure 2. Boxplot of monthly concentrations of $\mathrm{PM}_{2.5}, \mathrm{PM}_{10}$, and rainfall in Bogor for 2017-2019. 

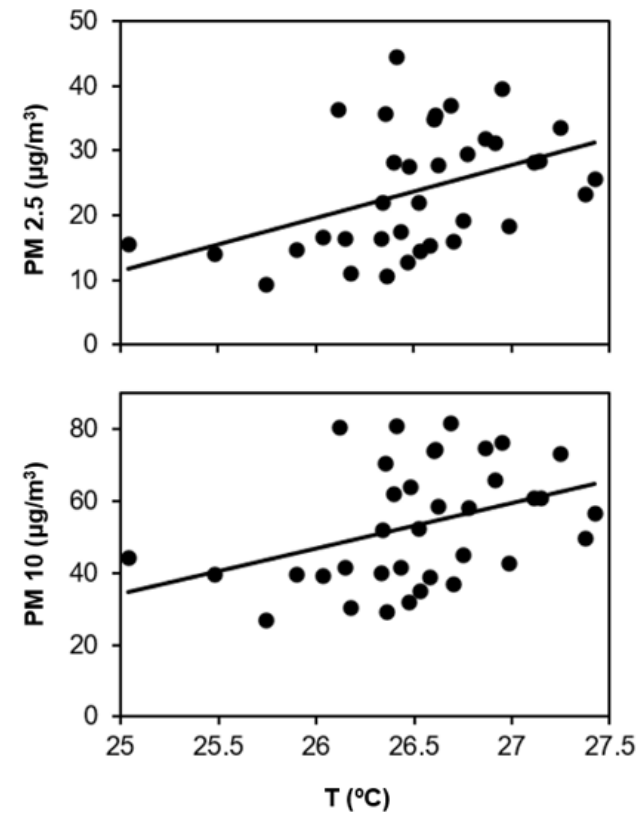
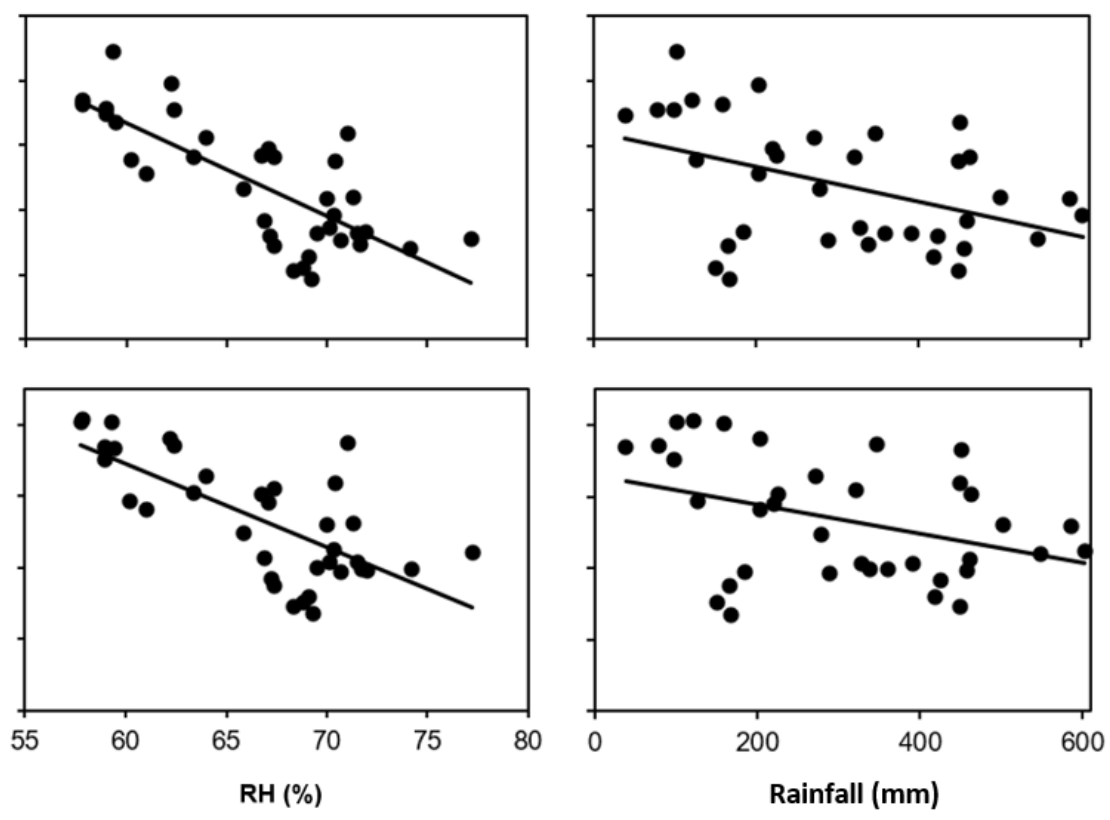

Another factor that can increase the concentration of PM during the dry season is high surface temperature and high air temperature which results in lower air density thus PM is more easily lifted from the surface and floats in the air and accumulates due to atmospheric circulation (Zalakeviciute et al., 2020).

\section{Pneumonia Incidence, Climatic Variables, and PM Concentration}

The total number of pneumonia incidence in children under five registered in ten health centers for the 2017-2019 period in Bogor was 2,380 from a total population of 94,902 in 2018 (around $\pm 2.5 \%$ of the total toddler's population in three years). Pneumonia incidence in Bogor showed an increasing trend from 2017 to 2019, with the highest rate arisen in 2019 (Figure 4e). The highest incidence of pneumonia occurred from wet season to transitional season from wet season to dry season which was in February and March. The peak incidence of pneumonia occurred during the dry season in July 2017 and 2019, also during the transitional season from dry to wet season which was in October 2018 with a lower peak compared to those in the wet season. This case will then become the basis for analysis of the pneumonia incidence categorized by season, which divided into the wet season in December-January-February (DJF), the transition from the wet to the dry season in MarchApril-May (MAM), the dry season in June-July-August (JJA), and the transition from the dry to the wet season in September-October-November (SON).

The pneumonia incidence in December to May had the same pattern as rainfall and relative humidity but had the opposite/inverse pattern to PM and air temperature. The pneumonia incidence from December to May occurred when rainfall and humidity increased (Figures 4a and 4d), which was in line with Ike and Mbonu's (2019) research, and when PM concentration and air temperature decrease (Figures $4 \mathrm{~b}$ and $4 \mathrm{c}$ ). On the contrary, the incidence of pneumonia in June to November has the same pattern as PM concentration and air temperature but has the opposite/inverse pattern to rainfall and air humidity. The incidence of pneumonia from June to November occurred when PM concentration and air temperature increases, while rainfall and humidity decreases, which was in line with Cahyadi et al. (2016) research.

The correlation between pneumonia incidence with climatic variables and PM concentration had the most statistically significant value in the transitional season. The correlation coefficient showed that pneumonia incidence in the MAM months was not only had a statistically significant negative correlation with air temperature, $\mathrm{PM}_{2.5}$, and $\mathrm{PM}_{10}$ but also had a significantly positive correlation with rainfall. At SON months, the pneumonia incidence was not only had a significantly positive correlation with $\mathrm{PM}_{2.5}$, and $\mathrm{PM}_{10}$ but also had a significant negative correlation with relative humidity (Table 1 ). The correlation value was calculated in a weekly period assuming that pneumonia symptoms became visible and hospital visits were carried out within a week. The correlation value obtained was low, arguably because there was a possible lag/gap between climatic variables and PM with the time the patient visits the hospital. Either climatic variables and PM can be combined and lead to cause pneumonia, but the mechanism will be vary depending on which was the most dominant. 
According to the overall correlation coefficient, the weekly pneumonia incidence in 2017-2019 had a significantly positive correlation with climatic variables (actual vapor pressure and relative humidity) and a significantly negative correlation with PM concentrations $\left(\mathrm{PM}_{2.5}\right.$ and $\left.\mathrm{PM}_{10}\right)$. The variable used for PCA in 2017-2019 was relative humidity (RH) to represent the humid condition in the wet season and $\mathrm{PM}_{2.5}$ which had a greater correlation with pneumonia compared to $\mathrm{PM}_{10}$.

PCA was performed to eliminate multicollinearity between $\mathrm{RH}$ and $\mathrm{PM}_{2.5}$ which had a significant negative correlation of -0.629 . The component used was only PC1 which represented $81 \%$ of the total pneumonia incidence. PC2 had an insignificant correlation with the incidence of pneumonia. The equation obtained is: Pneumonia = $17.046+1.990$ PC1, which then transformed back in the form of pneumonia regression equation with $\mathrm{RH}$ and $\mathrm{PM}_{2.5}$ as follows: Pneumonia $=-43.967+1.4 \mathrm{RH}-1.413$ $\mathrm{PM}_{2.5}$ and then plotted into a 3D-surface plot (Figure $5 a)$. The results of the 3D-surface plot showed that if humidity reached $80 \%$ and the $\mathrm{PM}_{2.5}$ concentration was relatively low $\left(<15 \mu \mathrm{g} / \mathrm{m}^{3}\right)$, the highest incidence of pneumonia was around 40 cases. This showed that humidity was mainly influenced pneumonia incidence in Bogor.
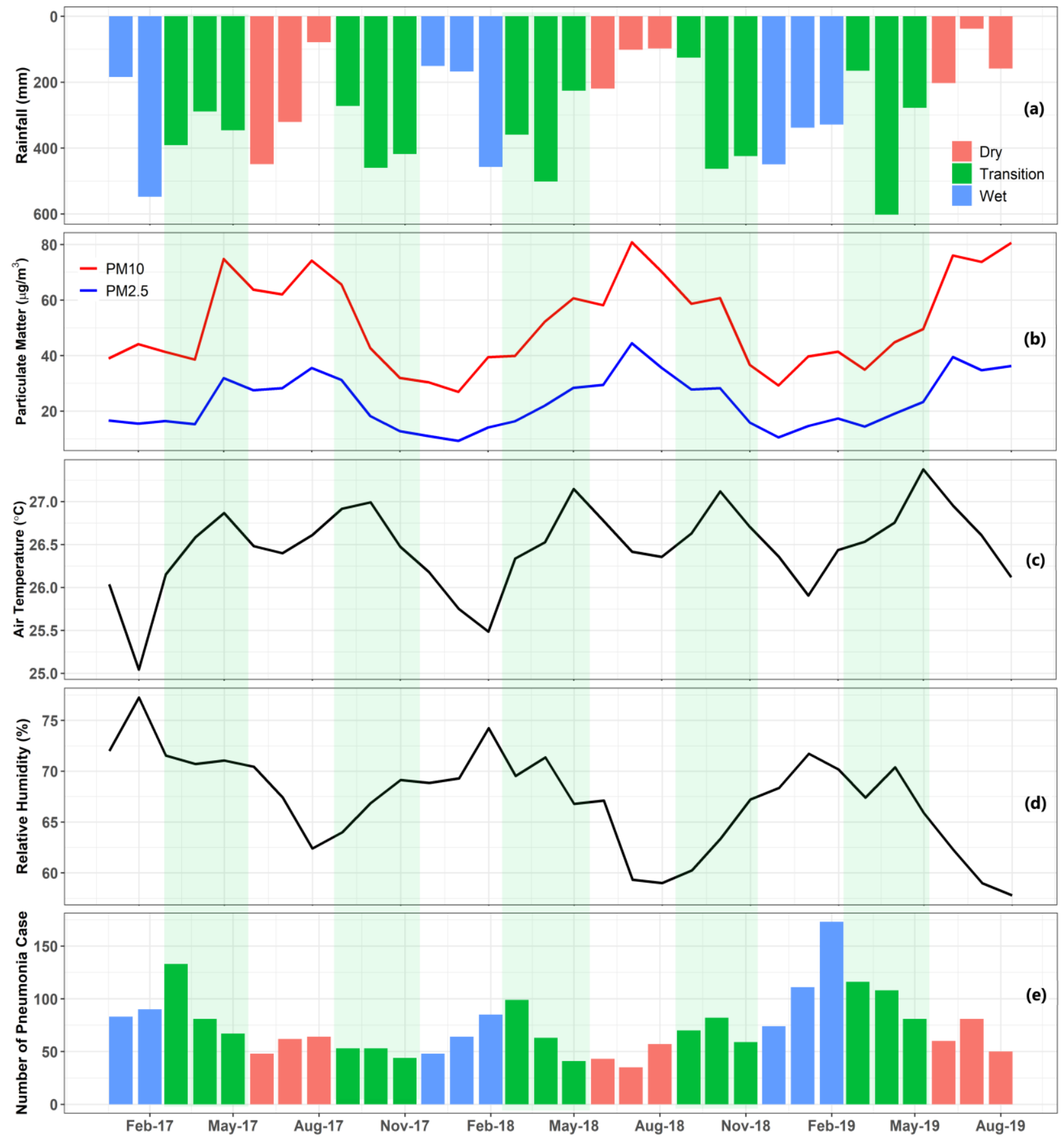

Figure 4. Monthly pattern of: (a) rainfall, (b) PM2.5 and PM10 consentration, (c) near-surface air temperature, (d) relative humidity, and (e) pneumonia incidence in Bogor in 2017-2019 period. 
Table 1. Correlation coefficient ( $r$ ) of pneumonia incidence with climate factors and PM concentration.

\begin{tabular}{ccccccc}
\hline & RH & Rainfall & $\mathbf{T}$ & ea & $\mathbf{P M}_{2.5}$ & $\mathbf{P M}_{\mathbf{1 0}}$ \\
\hline MAM & 0.18 & 0.40 & -0.43 & 0.01 & -0.44 & -0.42 \\
\hline$p_{-}$value & 0.237 & 0.009 & 0.005 & 0.945 & 0.003 & 0.005 \\
\hline SON & -0.54 & -0.14 & 0.35 & -0.51 & 0.58 & 0.59 \\
\hline$p_{\text {_value }}$ & 0.003 & 0.488 & 0.072 & 0.007 & 0.001 & 0.001 \\
\hline
\end{tabular}

Note: correlation was performed in a weekly period

The effect of PM on pneumonia was analyzed in SON months using PCA on the actual vapor pressure (ea) and $\mathrm{PM}_{2.5}$ concentration. PCA was performed to eliminate multicollinearity between ea and $\mathrm{PM}_{2.5}$ which had a significantly negative correlation of -0.508 . The component used was only PC1 which represented $78 \%$ of the total pneumonia incidence. PC2 had an insignificant correlation with the incidence of pneumonia. The equation obtained is: Pneumonia $=$ $13.583-2.584 \mathrm{PC} 1$, which then transformed back in the form of pneumonia regression equation with ea and $\mathrm{PM}_{2.5}$ as follows: Pneumonia $=6.993-1.827$ ea + $1.827 \mathrm{PM}_{2.5}$ and then plotted into a 3D-surface plot (Figure $5 \mathrm{~b}$ ). The results of the 3D-surface plot showed that if the actual vapor pressure was low and about $<19$ $\mathrm{hPa}$ and the $\mathrm{PM}_{2.5}$ concentration reached $40 \mu \mathrm{g} / \mathrm{m}^{3}$, the highest incidence of pneumonia occurred which was around 40 cases. This showed that $\mathrm{PM}_{2.5}$ had a more dominant influence during the dry period, especially in SON months (the transition season from the dry to the wet season).

According to Griffiths et al. (2017), the response of a toddler's body to pneumonia infection can be influenced by climatic variables through the respiratory tract sensor's sensitivity to weather changes. The incidence of pneumonia in the wet season is not directly affected by rainfall but influenced by the consequences of humid conditions, namely the increase of viruses growth and development, bacteria, and fungi which are dangerous when being inhaled (Ike and Mbonu, 2019; Jati and Ginandjar, 2017). The spores of atmospheric fungi and bacteria are varied in size, ranging from 1-10 $\mu \mathrm{m}$ (Gonzalez-Martin, 2019) which allows them to enter the respiratory tract. According to Adaji et al. (2019), indoor pollution during the wet season can also affect pneumonia incidence in children under five. The effect of indoor pollution including microorganisms is unidentifiable because it is unable to be measured by a standard PM gauge placed in an outdoor measuring station.

The result showed that pneumonia incidence may also occur in the dry season was in line with Cahyadi et al. (2016) and Hidayati et al. (2017). According to Tam et al. (2014) and Sahuquillo-Arce et al. (2017), in the dry season, the population of microorganisms causing respiratory infections did not grow rapidly due to dry conditions caused by lower humidity. However, when the humidity is low, the infection can also easily occur because mucosal fluids as a PM filter will be easier to dry so that more PM can be inhaled. High PM concentrations in the respiratory tract will lead to oxidative stress (when the number of free radicals in the body exceeds the body's capacity to neutralize them) resulting in tissue destruction. The damaged tissue will be more easily infected by the disease-causing viruses and bacteria combined with PM.

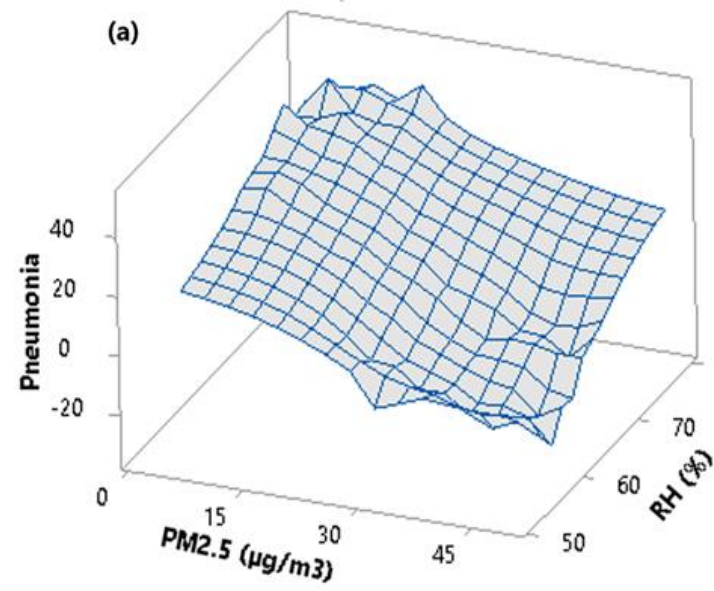

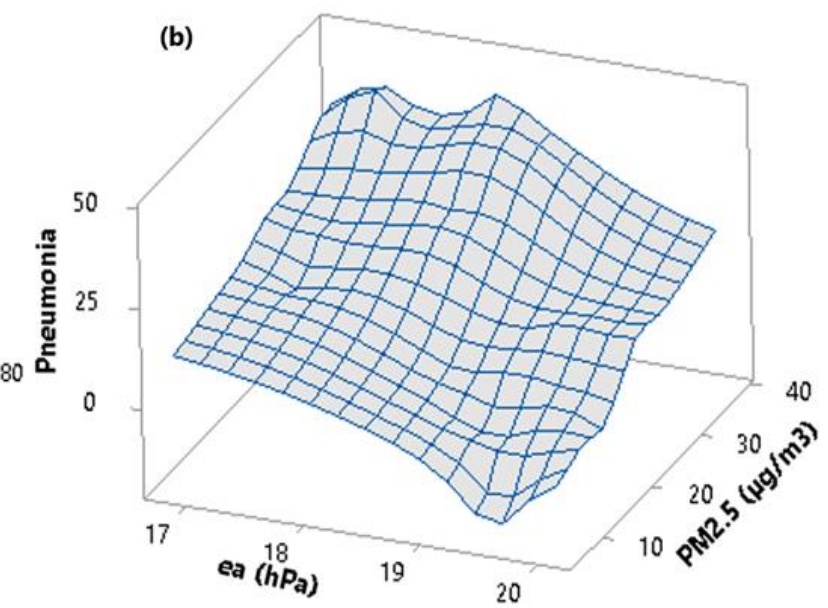

Figure 5. The 3D-Surface plot of (a) the Pneumonia incidence, $\mathrm{RH}$, and $\mathrm{PM}_{2.5}$ in 2017-2019, and (b) Pneumonia incidence, $\mathrm{RH}$, and $\mathrm{PM}_{2.5}$ in transition season (SON). 
The main factor causing pneumonia is the infection of microorganisms (bacteria and viruses) on the respiratory tract and organs, but the presence of microorganisms is not always related to pneumonia (Quinton et al., 2018; Sun et al., 2019; Suprobowati and Kurniati, 2018). Nevertheless, the infection also depends on the body conditions and its response to these microorganisms. Pneumonia microorganisms can spread through droplets from an infected person which are then inhaled or attached to another person's mucosal tissue. When microorganisms have entered and attached to the respiratory tract, these microorganisms will break into cells to multiply themselves using existing facilities in the cell then destroy the cell and move to another cell. The epithelial cells will then detect this activity and instruct the body's defense system (alveolar macrophages) to eat these microorganisms so that their proliferation and damage to cells can be immediately stopped. Pneumonia occurs when inflammation due to the inability of the body's defense system to fight microorganisms does not recover for a long time.

\section{CONCLUSIONS}

PM concentration in the atmosphere was mainly influenced by relative humidity with a correlation coefficient of -0.76 for $\mathrm{PM}_{2.5}$ and -0.71 for $\mathrm{PM}_{10}$ (with a 95\% confidence level). High rainfall and relative humidity during the wet season reduce $\mathrm{PM}_{2.5}$ and $\mathrm{PM}_{10}$. The trend of pneumonia incidence under 5-year children in Bogor in 2017-2019 had increased. The incidence of pneumonia reached 40 cases when the humidity was around $80 \%$ and the $\mathrm{PM}_{2.5}$ concentration was relatively low $\left(<15 \mu \mathrm{g} / \mathrm{m}^{3}\right)$. The $\mathrm{PM}_{2.5}$ concentration significantly affected the incidence of pneumonia in the transition season from the dry season to the wet season (September-October-November). The PCA results showed that the incidence of pneumonia in the dry season was also quite high, reached 40 cases when the actual vapor pressure (ea) was low $(<19 \mathrm{hPa})$ and the $\mathrm{PM}_{2.5}$ concentration reached $40 \mu \mathrm{g} / \mathrm{m}^{3}$.

\section{ACKNOWLEDGEMENT}

The authors would like to thank the CCROMSEAP IPB for their strong support and assistance by providing PM concentration data, climate data, and pneumonia data. This research had been presented in the $5^{\text {th }}$ Annual Meeting on GHGs and $\mathrm{AQ}$ Joint Monitoring in Indonesia on February $16^{\text {th }}, 2021$.

\section{REFERENCES}

Adaji, E.E., Ekezie, W., Clifford, M., Phalkey, R., 2019. Understanding the effect of indoor air pollution on pneumonia in children under 5 in low-and middle-income countries: a systematic review of evidence. Environmental Science and Pollution Research 26, 3208-3225. https://doi.org/10.1007/s11356-018-3769-1

Aida, R., Rohmawati, F.Y., Turyanti, A., 2019. The Effect of Car Free Day (CFD) on Pollutant Emissions at Alternative Roads (Case Study: RE Martadinata Street, Bogor). Agromet 33, 8-19. https://doi.org/10.29244/j.agromet.33.1.8-19

Cahyadi, W., Achmad, B., Suhartono, E., Razie, F., 2016. Pengaruh Faktor Meteorologis Dan Konsentrasi Partikulat (Pm10) Terhadap Kejadian Infeksi Saluran Pernapasan Akut (Ispa)(Studi Kasus Kecamatan Banjarbaru Selatan, Kota Banjarbaru Tahun 2014-2015). Enviroscienteae 12, 302-311. https://doi.org/10.20527/es.v12i3.2455

Chang, J., Liu, W., Huang, C., 2018. Residential ambient traffic in relation to childhood pneumonia among urban children in Shandong, China: A cross-sectional study. International journal of environmental research and public health 15 , 1076. https://doi.org/10.3390/ijerph15061076

Chowdhury, F.R., Ibrahim, Q.S.U., Bari, M.S., Alam, M.J., Dunachie, S.J., Rodriguez-Morales, A.J., Patwary, M.I., 2018. The association between temperature, rainfall and humidity with common climate-sensitive infectious diseases in Bangladesh. PloS one 13, e0199579. https://doi.org/10.1371/journal.pone.0199579

Darrow, L.A., Klein, M., Flanders, W.D., Mulholland, J.A., Tolbert, P.E., Strickland, M.J., 2014. Air pollution and acute respiratory infections among children $0-4$ years of age: an 18-year timeseries study. American journal of epidemiology 180, 968-977. https://doi.org/10.1093/aje/kwu234

Gonzalez-Martin, C., 2019. Airborne infectious microorganisms. Encyclopedia of Microbiology 52.

Griffiths, C., Drews, S.J., Marchant, D.J., 2017. Respiratory syncytial virus: infection, detection, and new options for prevention and treatment. Clinical microbiology reviews 30, 277-319. https://doi.org/10.1128/CMR.00010-16

Hidayat, R., Farihah, A.W., 2020. Identifikasi perubahan suhu udara dan curah hujan di Bogor. Jurnal Pengelolaan Sumberdaya Alam dan Lingkungan (Journal of Natural Resources and Environmental Management) 10, 616-626. https://doi.org/10.29244/jpsl.10.4.616-626

Hidayati, R., Anggiani, S.T., Maufikoh, I., 2017. Incidence Analysis of an Acute Respiratory Infection due to Climate Conditions and PM10 
Muharrami et al./Agromet 35 (1): 39-48, 2021

Concentration in West Jakarta Region.

Agromet 31, 62-70.

https://doi.org/10.29244/j.agromet.31.2.62-70

Ike, F., Mbonu, C., 2019. Effects of Weather and Climatic

Elements on the Incidence of Pneumonia in

Kaduna South Local Government Area, North

Western Nigeria. Earth Sciences 8, 126-131.

https://doi.org/10.11648/j.earth.20190803.11

Jati, S., Ginandjar, P., 2017. Potential impact of climate variability on respiratory diseases in infant and children in Semarang. Presented at the IOP Conference Series: Earth and Environmental Science, IOP Publishing, p. 012049. https://doi.org/10.1088/17551315/55/1/012049

Kemenkes, 2014. Profil Kesehatan Indonesia 2014. Kementrian Kesehatan RI, Jakarta.

Kwak, H.-Y., Ko, J., Lee, S., Joh, C.-H., 2017. Identifying the correlation between rainfall, traffic flow performance and air pollution concentration in Seoul using a path analysis. Transportation research procedia 25, 3552-3563. https://doi.org/10.1016/j.trpro.2017.05.288

Mathew, J.L., 2018. Etiology of Childhood Pneumonia: What We Know, and What We Need to Know! The Indian Journal of Pediatrics 85, 25-34. https://doi.org/10.1007/s12098-017-2486-y

McLoughlin, R.F., Berthon, B.S., Williams, E.J., Wood, L.G., 2019. Vitamin $E$ and Air Pollution, in: Vitamin $E$ in Human Health. Springer, pp. 385-403.

Mehta, S., Shin, H., Burnett, R., North, T., Cohen, A.J., 2013. Ambient particulate air pollution and acute lower respiratory infections: a systematic review and implications for estimating the global burden of disease. Air Quality, Atmosphere \& Health 6, 69-83. https://doi.org/10.1007/s11869-011-0146-3

Nathan, A.M., Teh, C.S.J., Jabar, K.A., Teoh, B.T., Tangaperumal, A., Westerhout, C., Zaki, R., Eg, K.P., Thavagnanam, S., de Bruyne, J.A., 2020. Bacterial pneumonia and its associated factors in children from a developing country: A prospective cohort study. Plos one 15 , e0228056.

https://doi.org/10.1371/journal.pone.0228056

Nishihashi, M., Mukai, H., Terao, Y., Hashimoto, S., Osonoi, Y., Boer, R., Ardiansyah, M., Budianto, B., Immanuel, G.S., Rakhman, A., Nugroho, R., Suwedi, N., Rifai, A., Ihsan, I.M., Sulaiman, A., Gunawan, D., Suharguniyawan, E., Nugraha, M.S., Wattimena, R.C., Ilahi, A.F., 2019. Greenhouse gases and air pollutants monitoring project around Jakarta megacity. IOP Conf. Ser.: Earth Environ. Sci. 303, 012038. https://doi.org/10.1088/1755-

1315/303/1/012038

Pedde, M., Szpiro, A.A., Adar, S.D., 2017. Traffic congestion as a risk factor for mortality in nearroad communities: a case-crossover study. American journal of epidemiology 186, 564572. https://doi.org/10.1093/aje/kwx130

Popovsky, E.Y., Florin, T.A., 2020. Community-Acquired Pneumonia in Childhood. Reference Module in Biomedical Sciences. https://doi.org/10.1016/B978-0-08-1027233.00013-5

Putra, Y., Wulandari, S.S., 2019. Faktor Penyebab Kejadian Ispa. Jurnal Kesehatan 10, 37-40. https://doi.org/10.35730/jk.v10i1.378.g438

Quinton, L.J., Walkey, A.J., Mizgerd, J.P., 2018. Integrative physiology of pneumonia. Physiological reviews 98, 1417-1464. https://doi.org/10.1152/physrev.00032.2017

Rodrigues, C., Groves, H., 2018. Community-acquired pneumonia in children: the challenges of microbiological diagnosis. Journal of clinical microbiology 56. https://doi.org/10.1128/JCM.01318-17

Ruchiraset, A., Tantrakarnapa, K., 2020. Association of climate factors and air pollutants with pneumonia incidence in Lampang province, Thailand: findings from a 12-year longitudinal study. null 1-10. https://doi.org/10.1080/09603123.2020.17939 19

Sahuquillo-Arce, J.M., Ibáñez-Martínez, E., HernándezCabezas, A., Ruiz-Gaitán, A., Falomir-Salcedo, P. Menéndez, R., López-Hontangas, J.L., 2017. Influence of environmental conditions and pollution on the incidence of Streptococcus pneumoniae infections. ERJ open research 3. https://doi.org/10.1183/23120541.00014-2017

Satsangi, D., Agarwal, A., 2019. Particulate Matter and Its Impact on Human Health in Urban Settings. pp. 213-231. https://doi.org/10.1007/978-98113-3287-6_10

Sidiq, R., Ritawati, R., Sitio, R., Hajar, S., 2016. The Risk of Pneumonia among Toddlers in Lambatee, Aceh. Kesmas: Jurnal Kesehatan Masyarakat Nasional (National Public Health Journal) 11, 69-73. https://doi.org/10.21109/kesmas.v11i2.1044

Sohn, S., Cho, W., Kim, J.A., Altaluoni, A., Hong, K., Chun, B.C., 2019. 'Pneumonia weather': short-term effects of meteorological factors on emergency room visits due to pneumonia in Seoul, Korea. Journal of Preventive Medicine and Public 
Health

52,

82.

https://doi.org/10.3961/jpmph.18.232

Sun, S., Tian, L., Cao, W., Lai, P.-C., Wong, P.P.Y., Lee, R.S., Mason, T.G., Krämer, A., Wong, C.-M., 2019. Urban climate modified short-term association of air pollution with pneumonia mortality in Hong Kong. Science of the Total Environment 646, 618-624. https://doi.org/10.1016/j.scitotenv.2018.07.31 1

Suprobowati, P., Kurniati, L., 2018. Virologi, in: Bahan Ajar Taknologi Laboratorium Medik. Kementrian Kesehatan RI, Jakarta.

Tam, W.W., Wong, T.W., Ng, L., Wong, S.Y., Kung, K.K., Wong, A.H., 2014. Association between air pollution and general outpatient clinic consultations for upper respiratory tract infections in Hong Kong. PLoS One 9, e86913. https://doi.org/10.1371/journal.pone.0086913

Turyanti, A., 2011. Analisis Pengaruh Faktor Meteorologi Terhadap Konsentrasi PM10 Menggunakan Regresi Linier Berganda (Studi Kasus: Daerah Dago Pakar dan Cisaranten Bandung). Agromet 25, 29-36. https://doi.org/10.29244/j.agromet.25.1.29-36

Turyanti, A., Chaerunnisa, C., 2017. The Estimation of Rainwater Acidity Level based on the Ambient Air Pollutants Concentration (Case Study: DKI
Jakarta). Agromet 31, 71-79. https://doi.org/10.29244/j.agromet.31.2.71-79

Turyanti, A., Santikayasa, I.P., 2006. Analisis Pola Unsur Meteorologi dan Konsentrasi Polutan di Udara Ambien Sudi Kasus: Jakarta dan Bandung. Agromet 20, 25-37. https://doi.org/10.29244/j.agromet.20.2.25-37

Vodonos, A., Kloog, I., Boehm, L., Novack, V., 2016. The impact of exposure to particulate air pollution from non-anthropogenic sources on hospital admissions due to pneumonia. European Respiratory Journal 48, 1791-1794. https://doi.org/10.1183/13993003.01104-2016

WHO, 2014. Infection Prevention and Control of Epidemic-and pandemic-prone Acute Respiratory Infections in Health Care. World Health Organization, Geneva.

Widoyo, R., 2016. Measles Immunization and Vitamin A for Prevention of Pneumonia in Indonesia. Kesmas: Jurnal Kesehatan Masyarakat Nasional (National Public Health Journal) 11, 46-50. https://doi.org/10.21109/kesmas.v11i1.841

Zalakeviciute, R., Alexandrino, K., Rybarczyk, Y., Debut, A., Vizuete, K., Diaz, M., 2020. Seasonal variations in PM 10 inorganic composition in the Andean city. Scientific reports 10, 1-13. https://doi.org/10.1038/s41598-020-72541-2 